\title{
Determination of economic efficiency of agricultural enterprises in Turkey: a DEA approach
}

\author{
Erdogan Gunes*, Huseyin Tayyar Guldal*
}

DOI: $10.30682 / \mathrm{nm} 1904 \mathrm{~h}$

JEL codes: Q12, Q14

\begin{abstract}
In this study, it is tried to determine the efficiencies of agricultural enterprises in the use of capital and credit in Turkey by DEA. In the scope of the study, 550 farmers in enterprises in Antalya, Konya, Karaman, Ankara, and Eskişehir were interviewed. According to the results of the data envelopment analysis, 95 farmers according to CRS, 134 according to under VRS, and 95 according to under SE were found to be effective. The higher average of the overall technical efficiency is Antalya (0.87) and Konya (0.72). This result shows that even if the agricultural enterprises reduce input use by $13 \%$ in Antalya and $28 \%$ in Konya, they will achieve the same agricultural income. According to the research results, it is determined that agricultural enterprises in Turkey do not use effectively the capitals, and they can achieve the same agricultural income with a low level of capital. Keeping the accounting records of agricultural enterprises in Turkey is important in terms of making a proper production plan.
\end{abstract}

Keywords: Data envelopment analysis, Mediterranean, Capital, Credit, Turkey.

\section{Introduction}

The rapid increase in the world population increases the nutritional needs accordingly. Although nutrient consumption shows an alteration depending on the level of development of countries, cereals and wheat are the main source of nutrients for feeding. In acreage, cereal crops are the most important in Mediterranean agriculture. Wheat, especially hard winter wheat, is the principal food grain, and barley is grown in the poorer areas.
In Turkey which is the most cereals producer in Mediterranean countries, it is seen high price volatility in the cereals market (Çınar, 2018) (Fig. 1).

Increasing volatilities in food prices have impacts on the incomes of the farmers (Enjolras et al, 2014), these volatilities lead to uncertainty and making investment decisions that are not optimal (Guillen and Franquesa, 2015). Accordingly, making an accurate way of farmers' production decisions and planning in Turkey, it is important in terms of ensuring and enhancing

\footnotetext{
* Department of Agricultural Economics, Ankara University, Ankara, Turkey.

Corresponding author: htguldal@ankara.edu.tr
} 
the sustainability of grain production. In order to ensure the continuity of production in agricultural enterprises, farmers must maintain their livelihood and create resources for new investments. In this context, agricultural income is an important criterion of success and consists of equity and the sum of the wages he and his family earn for work. In addition to the living cost of the family, farmers have to cover the investments to be made and the taxes to be paid by the agricultural income. If agricultural income cannot meet these costs, there may be a decrease in working capital. The appropriateness of agricultural capital to the enterprises structure is considered to be an important factor in the rantable work of the enterprise.

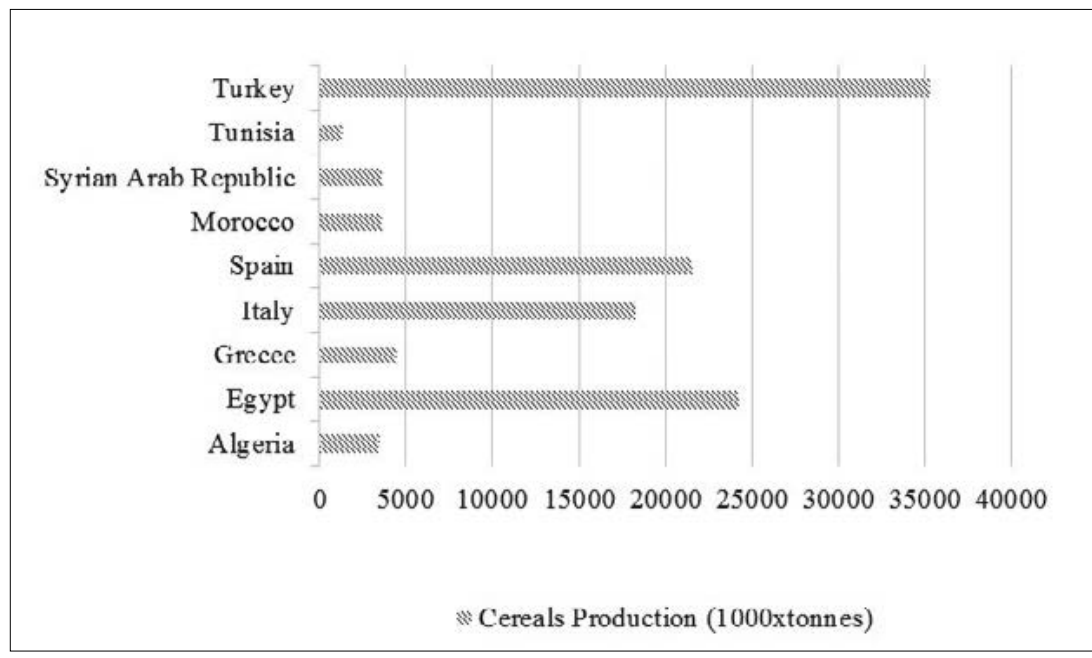

Source: FAO, 2018.
Figure 1 - Cereals Production In Mediterranean Countries (2016) (1000 $\mathrm{x}$ tonnes).
Distribution of the elements of the capital is as important as the amount of capital in the enterprises success. Depending on the type and size of the enterprises, a certain amount of various capital must be available for an enterprises to function normally (Aksöz, 1972). It has been identified in the research that the largest share in the active capitals of Turkish agriculture enterprises belongs to land capital (Sayılı and Esengün, 2002; Özkan and Erkuş, 2003; Arısoy, 2004; Şili, 2013; Aydın, 2014). This is because land capital is more than other capital groups. This is an indicator of extensive agriculture. In this case, enterprises avoid new investments to increase agricultural income.

In addition to land capital, balanced use of money capital which is in an active is one of the factors affecting agricultural income. Due to low agricultural income in Turkey, enterprises need foreign capital. The most common way of providing foreign capital is agricultural credit. Credit systems contribute to the sustainability of production due to the indispensability of agriculture in nutrition (Bishoff, 2008). There are many studies examining the effects of agricultural credit on agricultural enterprises (Zuberi, 1989; Feder et al., 1990; Khandker and Faruqee, 2003; Abdallah, 2016; Chandio et al., 2017). In spite of the increasing use of agricultural credits, these credits are not used correctly and effectively. Therefore, debates on credit effectiveness come up. As a result of the use of agricultural credit in non-agricultural activities, the failure to make credit planning correctly, and the excessive use of credit dragging farmers into debt, enterprises are experiencing difficulties in repayments (Hundie et al., 2004; Katchova, 2005; Ünlüer and Güneş, 2013). Debt expansion will 
increase debt interest and reduce agricultural income in agricultural enterprises ${ }^{1}$.

In this context, the aim of the study is to determine the effectiveness of agricultural enterprises in Turkey which has an important role of cereal production for Mediterranean countries and analyze the elements that are inactive. This is a matter to be discussed widely due to Turkey can't meet domestic demand.

In many research, the methods used in measurement of efficiency are generally divided into parametric methods and non-parametric methods. The most common method in the literature is Data Envelopment Analysis (DEA) which is a non-parametric method. DEA, a leading analytical technique for measuring relative efficiency, has been widely used by both academic researchers and practitioners in evaluating the efficiency of decision making units in terms of converting inputs into outputs. Researchers choose this technique because it does not impose a priori functional form and allows for multiple output technologies (Badunenko and Mozharovskyi, 2016). Data envelopment analysis was generally used to measure the effectiveness of inputs (Fraser and Cordina, 1999; Dhungana et al., 2004; Alemdar and Oren, 2006; Chebil et al., 2015; Igwe et al., 2017) that affect yield in scientific research related to agriculture economics. In this study, the structure of capital and credit status in agricultural enterprises has been investigated its effects on agricultural income. In particular geopolitical position of Turkey is an important country in cereal production, as well as problems in the accurate determination of the amount of capital due to the retention of agricultural accounting records of the enterprises, increase the importance of this study.

\section{Materials and methods}

\subsection{Data Envelopment Analysis (DEA)}

DEA, which is one of the commonly used methods in non-parametric methods, is a line- ar programming-based efficiency measurement method which is developed to measure the relative effectiveness of economic decision-making units when the inputs and outputs are measured with multiple and different scales or when the inputs and outputs with different measurement units make comparison difficult (Boussofiane et al., 1991). DEA assumes that each decision unit will select the input and output weights to maximize their efficiency (Doyle and Green, 1994).

The DEA models have been frequently applied in agriculture due to their advantages. The first DEA model for estimating technical efficiency was suggested by Charnes et al. (1978) and was based upon the assumption of constant returns to scale.

$$
\begin{array}{ll}
\operatorname{Min}_{\lambda, \theta} \theta & \\
\text { st } & -y i+Y \lambda \geq 0 \\
& \theta x_{\mathrm{i}}-X \lambda \geq 0 \\
& \lambda \geq 0
\end{array}
$$

Banker et al. (1984) redeveloped the first DEA model considering the variable return to scale (VRS) by adding the convexity constraint $\mathrm{N} 1$ ' $\lambda$ $=1$. The use of the CRS specification when not all farms are operating at the optimal scale will result in measures of TE which are confounded by scale efficiencies (SE). An input-oriented $\mathrm{BCC}$ model is given below for N Decision Making Units (DMU), each producing $\mathrm{M}$ outputs by using $\mathrm{K}$ different.

$$
\begin{aligned}
& \operatorname{Min}_{\lambda, \theta} \theta \\
& \text { st } \quad-y_{i}+Y \lambda \geq 0 \\
& \theta x_{\mathrm{i}}-X \lambda \geq 0 \\
& \mathrm{~N} 1^{\prime} \lambda=1 \\
& \lambda \geq 0
\end{aligned}
$$

where $\theta$ is a scalar, $\mathrm{N} 1^{\prime}$ is convexity constraint and while $\lambda$ is $N \times 1$ vector of constants. This envelopment form requires less constraints than multiplier form therefore it is in generally preferred to find the solution of the value of $\theta$ as we get the efficiency score for each of the farmer. If the value of $\theta=1$, then it shows that ith

Agricultural Income $=$ Pure Product $-($ Debt Interest + Rent $)+$ Family Labour Shadow Price 
farmer is on the frontier and hence a technically efficient farm (Farrel, 1957).

In this study, we use the input-oriented BCC model where the estimated efficiency scores typically indicate how much a farm should be able to reduce the use of all of its inputs as compared to the best performers.

\section{Study Area and Data Sources}

\subsection{Data sources}

Antalya, Konya, Ankara, Karaman, and Eskişehir provinces were selected as the research areas and a total of 550 farmers were randomly chosen of which 110 from per city during the 2014-2015 agricultural production season. These cities not just consist of $19 \%$ of arable land in Turkey (TurkStat, 2018), but they are also the places where some of the crop groups, which have a significant share in the export of agricultural products (wheat, barley, citrus etc.) are intensively cultivated.

In the determination of provinces and enterprises, the effect of the difference in production pattern and agricultural income were also taken into consideration. Furthermore, among these provinces, Konya, Ankara, and Antalya are among the top 10 in the use of agricultural credits in Turkey (Brsa, 2017). The agricultural production system (plant production and livestock) applied in provinces and intensive productions also require significant credit utilization and these criteria are considered among the main reasons of determination.

\subsection{Variables in the empirical analysis}

In the study, an output (agricultural income) and ten inputs (land, non-agricultural income, debts, land capital, reclamation of land capital, building capital, plant capital, tool-machine capital, material ammunition capital, and agricultural credits) were used in the research in DEA model. Descriptive statistics by provinces in the enterprises examined in the study are shown in Table 1 . The distribution of the capital by the function is generally taken into consideration in the analysis and planning of the agricultural enterprises. In this context, land capital (irrigated land, barren land, vineyard, orchard etc.), reclamation of land capital (irrigation canal, drainage facilities etc.), building capital (byre, bin etc.), plant capital (fruit trees etc.), tool-machine capital, material ammunition capital and money capital (agricultural credit etc.) are involved in active capital whereas debts are involved in passive capital. It is recommended that agriculture enterprises constitute their capital rates cautiously such as $25 \%$ of land capital, $25 \%$ of building capital, $25 \%$ of animal capital, $10 \%$ of tool- machine capital, $10 \%$ of material ammunition capital and $5 \%$ of money capital.

According to this, the average land widths in enterprises are determined as 84.77 in Antalya, 120.97 in Konya, 340.02 in Ankara, 180.09 in Karaman and 208.39 in Eskişehir (Table 1).

Agricultural income determined as output is the most common factor used to measure the success of the enterprise. Another common criterion for success measurement is the pure product, which is an objective measure of determining the success of the enterprises, however, does not fully represent the real income of the farmer family. Since, in the calculation of the pure product, it is assumed that the enterprises only process their own property lands and they are deemed to be indebted, the interest expenses of the foreign capital belong to the pure product. In this case, a farmer who seems to be successful according to the pure product may have paid a large portion of the pure product as tenancy expenses and debt interest. According to the results of the study, farmers with the highest average agricultural income were found in Antalya, followed by Konya, Eskişehir, Ankara, and Karaman.

When the agricultural credit usage amounts of the enterprises are examined, the enterprises in Karaman province take the first place with an average credit amount of 76 thousand Turkish lira whereas Antalya province takes the last place with an average credit amount of 14 thousand Turkish lira. 


\begin{tabular}{|c|c|c|c|c|c|c|c|c|c|c|c|c|c|c|}
\hline \multirow{2}{*}{ 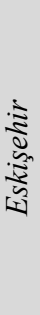 } & 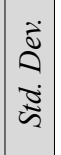 & & $\begin{array}{l}\tilde{n} \\
\tilde{\infty} \\
\infty \\
-1\end{array}$ & $\begin{array}{l}= \\
\vec{a} \\
\stackrel{\approx}{n}\end{array}$ & $\begin{array}{l}\hat{\sigma} \\
\grave{0} \\
\stackrel{0}{n} \\
m\end{array}$ & 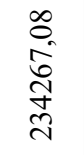 & $\begin{array}{l}\text { o } \\
\text { o } \\
\text { ț } \\
\text { n) }\end{array}$ & \begin{tabular}{l}
0 \\
\multirow{2}{*}{} \\
$\stackrel{0}{0}$ \\
$\stackrel{1}{I}$
\end{tabular} & $\frac{\hat{m}}{\hat{8}}$ & \begin{tabular}{l}
$\stackrel{2}{n}$ \\
\multirow{\pm}{n}{} \\
$\stackrel{n}{n}$
\end{tabular} & $\begin{array}{l}\vec{n} \\
\vec{o} \\
\dot{a}\end{array}$ & 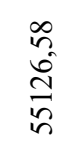 & & $\begin{array}{l}\stackrel{8}{+} \\
\hat{\sim} \\
\stackrel{\infty}{\infty}\end{array}$ \\
\hline & 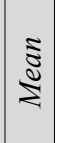 & & $\begin{array}{l}\hat{m} \\
\infty \\
\stackrel{i}{2}\end{array}$ & $\begin{array}{l}\dot{\circ} \\
\dot{8} \\
\dot{8} \\
\delta\end{array}$ & 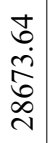 & 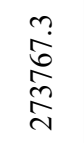 & $\begin{array}{l}\stackrel{n}{a} \\
\stackrel{n}{n} \\
\check{n}\end{array}$ & $\begin{array}{l}\vec{\sigma} \\
\dot{0} \\
\vec{\forall} \\
\dot{n}\end{array}$ & $\begin{array}{l}\text { No } \\
\stackrel{\infty}{\infty} \\
\stackrel{\infty}{0} \\
\sim\end{array}$ & $\begin{array}{l}\infty \\
\stackrel{\infty}{\circ} \\
\stackrel{\infty}{0} \\
\stackrel{0}{2}\end{array}$ & $\begin{array}{l}\hat{a} \\
\dot{0} \\
\hat{\sigma}\end{array}$ & 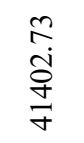 & & 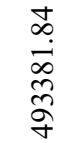 \\
\hline \multirow{2}{*}{ 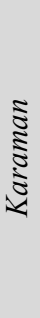 } & $\mid \begin{array}{c}\vec{\Xi} \\
0 \\
\vec{\Xi} \\
\vdots\end{array}$ & & $\begin{array}{l}\bar{n} \\
n \\
n\end{array}$ & 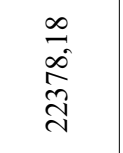 & 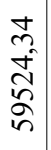 & $\begin{array}{l}0 \\
2 \\
\hat{0} \\
0 \\
\infty \\
\infty \\
-1\end{array}$ & $\begin{array}{l}\dot{J} \\
\overrightarrow{0} \\
\stackrel{े}{d}\end{array}$ & 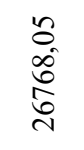 & 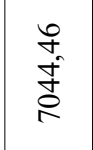 & 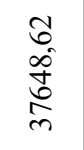 & 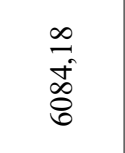 & $\begin{array}{l}0 \\
\stackrel{2}{2} \\
\stackrel{1}{N} \\
\end{array}$ & & 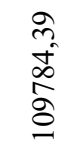 \\
\hline & $\begin{array}{c}\tilde{z} \\
\mathbb{z}\end{array}$ & & $\begin{array}{l}8 \\
\dot{\infty} \\
\infty \\
-\end{array}$ & $\begin{array}{l}\bar{\sigma} \\
0 \\
0 \\
\sigma\end{array}$ & $\begin{array}{l}\hat{b} \\
\dot{0} \\
\stackrel{7}{f} \\
\tilde{f}\end{array}$ & $\begin{array}{l}\stackrel{\sim}{\sim} \\
\underset{\sim}{\sim}\end{array}$ & $\begin{array}{l}\vec{J} \\
\stackrel{\sigma}{\sigma} \\
\stackrel{\sim}{v}\end{array}$ & $\begin{array}{l}\bar{\sigma} \\
\stackrel{0}{\hat{\sigma}} \\
i\end{array}$ & 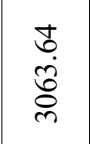 & $\begin{array}{l}\hat{N} \\
\frac{\hat{\sigma}}{\sigma} \\
\frac{\pi}{a}\end{array}$ & $\begin{array}{l}\infty \\
\infty \\
\hat{n} \\
\hat{n}\end{array}$ & $\begin{array}{l}n \\
n \\
2 \\
\tilde{n} \\
n\end{array}$ & & 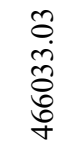 \\
\hline \multirow{2}{*}{$\frac{\pi}{\frac{1}{3}}$} & $\begin{array}{c}\overrightarrow{0} \\
\stackrel{0}{0} \\
\tilde{\Xi}\end{array}$ & & 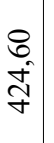 & $\begin{array}{l}\text { ò } \\
\text { i } \\
\text { o } \\
\text { d }\end{array}$ & $\begin{array}{l}\hat{n} \\
\hat{0} \\
\dot{0} \\
o \\
\dot{f}\end{array}$ & 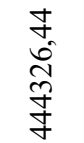 & $\begin{array}{l}\stackrel{n}{2} \\
\stackrel{\infty}{n}\end{array}$ & $\begin{array}{l}\infty \\
\infty \\
0 \\
\hat{n} \\
\hat{n} \\
\end{array}$ & $\begin{array}{l}\stackrel{a}{a} \\
\stackrel{\infty}{0} \\
\stackrel{2}{n}\end{array}$ & $\begin{array}{l}\text { I } \\
\stackrel{\text { Iิ }}{\text { I }}\end{array}$ & $\begin{array}{l}+ \\
\infty \\
0 \\
\infty \\
\stackrel{0}{2}\end{array}$ & 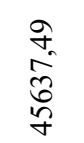 & & $\begin{array}{l}\infty \\
\infty \\
\infty \\
\infty \\
\infty \\
0\end{array}$ \\
\hline & $\begin{array}{l}\tilde{\Xi} \\
\Xi\end{array}$ & & 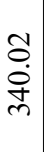 & $\begin{array}{l}\vec{n} \\
\infty \\
\stackrel{\infty}{n}\end{array}$ & 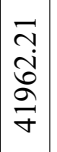 & 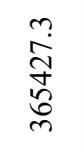 & $\begin{array}{l}\bar{a} \\
\text { ळे } \\
\text { ले }\end{array}$ & $\underset{\substack{n \\
\stackrel{n}{n}}}{\stackrel{m}{n}}$ & 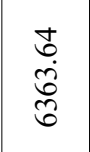 & $\begin{array}{l}\bar{a} \\
\stackrel{\circ}{\circ} \\
\frac{\alpha}{\alpha}\end{array}$ & $\begin{array}{l}\text { o. } \\
\text { ते } \\
\text { ลू. }\end{array}$ & 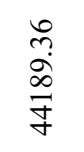 & & $\begin{array}{l}\hat{\sigma} \\
\stackrel{+}{+} \\
\stackrel{+}{\infty}\end{array}$ \\
\hline \multirow{2}{*}{ 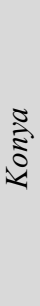 } & 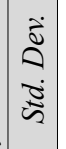 & & $\begin{array}{c}\hat{\lambda} \\
\tilde{\infty}\end{array}$ & $\begin{array}{l}\hat{\sigma} \\
\hat{n} \\
\hat{n} \\
\hat{v}\end{array}$ & 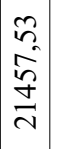 & $\begin{array}{l}\overrightarrow{0} \\
\vec{g} \\
\text { o } \\
0\end{array}$ & ڤू. & 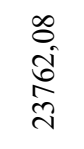 & 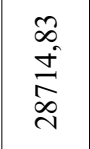 & $\begin{array}{l}\overrightarrow{0} \\
\text { đi } \\
\text { ర్ } \\
+\end{array}$ & $\begin{array}{l}\vec{\sigma} \\
\underset{\sigma}{m} \\
\text { m. }\end{array}$ & $\begin{array}{l}\bar{n} \\
\tilde{n} \\
i \\
i n\end{array}$ & & 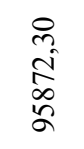 \\
\hline & $\begin{array}{l}\tilde{\Xi} \\
\mathbf{z}\end{array}$ & & $\begin{array}{l}\hat{\sigma} \\
\grave{\Xi}\end{array}$ & 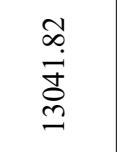 & $\begin{array}{c}\infty \\
\dot{\infty} \\
\stackrel{D}{J} \\
I\end{array}$ & $\begin{array}{l}\infty \\
0 \\
\stackrel{0}{0} \\
\infty \\
\infty \\
-\end{array}$ & 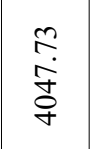 & $\begin{array}{l}\bar{a} \\
\stackrel{\lambda}{ } \\
\infty \\
\infty \\
\tilde{n}\end{array}$ & $\begin{array}{l}\stackrel{\partial}{0} \\
\stackrel{\partial}{ } \\
\stackrel{0}{\sim}\end{array}$ & $\begin{array}{l}\bar{\sigma} \\
\ddot{o} \\
\stackrel{+}{a} \\
\sigma\end{array}$ & 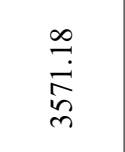 & 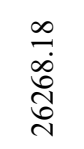 & & 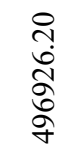 \\
\hline \multirow{2}{*}{ 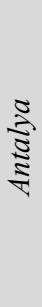 } & 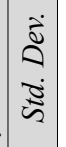 & & $\frac{n}{n}$ & $\begin{array}{l}\overrightarrow{0} \\
\stackrel{a}{y} \\
\stackrel{I}{I}\end{array}$ & $\frac{n}{n}$ & $\begin{array}{l}\stackrel{2}{2} \\
\stackrel{a}{a} \\
\frac{n}{\infty}\end{array}$ & $\begin{array}{l}\vec{ָ} \\
\stackrel{\Xi}{\sigma}\end{array}$ & 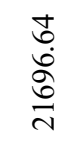 & $\begin{array}{l}\cong \\
\stackrel{+}{+} \\
\infty \\
\infty \\
\infty\end{array}$ & $\begin{array}{l}\text { ণั. } \\
\text { ळे } \\
\text { ळे }\end{array}$ & $\begin{array}{l}\stackrel{8}{\circ} \\
\dot{+} \\
\stackrel{\Xi}{=}\end{array}$ & $\begin{array}{l}\overrightarrow{0} \\
\dot{+} \\
\text { o } \\
\dot{+}\end{array}$ & & $\begin{array}{l}\text { ñ } \\
\stackrel{2}{2} \\
\stackrel{2}{n} \\
\end{array}$ \\
\hline & $\underset{\Xi}{\Xi}$ & & $\begin{array}{l}\hat{\vartheta} \\
\dot{\infty}\end{array}$ & 志 & $\mid \begin{array}{l}\infty \\
\infty \\
\infty \\
\infty \\
\alpha \\
\alpha\end{array}$ & $\frac{n}{n}$ & $\begin{array}{l}\bar{\sigma} \\
\dot{\delta} \\
\stackrel{\Delta}{\Delta}\end{array}$ & $\underset{n}{\stackrel{n}{*}}$ & $\begin{array}{l}\bar{\sigma} \\
\hat{\sigma} \\
\hat{n} \\
\dot{n}\end{array}$ & 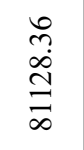 & $\begin{array}{l}\hat{n} \\
\tilde{n} \\
\tilde{n}\end{array}$ & 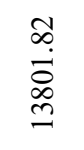 & & $\begin{array}{l}8 \\
\stackrel{8}{1} \\
\stackrel{1}{a} \\
\infty \\
i n \\
i n\end{array}$ \\
\hline & 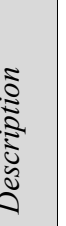 & 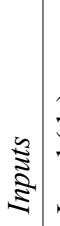 & 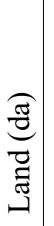 & 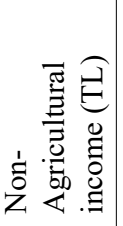 & 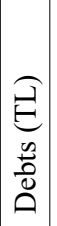 & 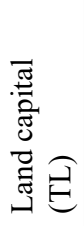 & 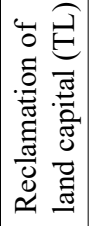 & 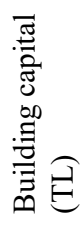 & 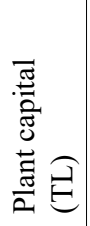 & 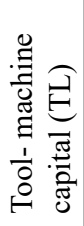 & 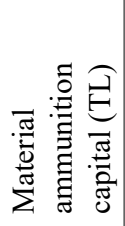 & 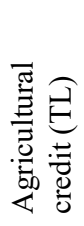 & 离 & 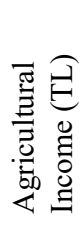 \\
\hline
\end{tabular}




\section{Result and Discussions}

Within the scope of the research, MaxDEA 7 program was used to determine activity scores of enterprises. As a result of the DEA analysis, constant return to scale (CRS) to scale, variable return to scale (VRS) and scale efficiency (SE) results are given in Table 2.

While 95 of the enterprises were found to be effective under CRS, this figure was 134 under VRS. The efficiency scores of enterprises under CRS 145 and under VRS 74 are below 0.50 .

Table 2 - Number of farms under different variants of efficiency.

\begin{tabular}{|c|c|c|c|c|c|c|}
\hline Efficiency Level & $\begin{array}{c}\text { Number of farms } \\
\text { under CRS TE }\end{array}$ & $\%$ & $\begin{array}{c}\text { Number of farms } \\
\text { under VRS TE }\end{array}$ & $\%$ & $\begin{array}{c}\text { Number of farms } \\
\text { under } S E\end{array}$ & $\%$ \\
\hline Below 0.50 & 145 & 26.36 & 74 & 13.45 & 7 & 1.27 \\
\hline $0.50-0.60$ & 71 & 12.91 & 86 & 15.64 & 12 & 2.18 \\
\hline $0.60-0.70$ & 83 & 15.09 & 87 & 15.82 & 17 & 3.09 \\
\hline $0.70-0.80$ & 51 & 9.27 & 67 & 12.18 & 45 & 8.18 \\
\hline $0.80-0.90$ & 56 & 10.18 & 53 & 9.64 & 120 & 21.82 \\
\hline $0.90-0.99$ & 49 & 8.91 & 49 & 8.91 & 254 & 46.18 \\
\hline 1 & 95 & 17.27 & 134 & 24.36 & 95 & 17.27 \\
\hline Total no of farmers & 550 & 100.0 & 550 & 100.0 & 550 & 100.0 \\
\hline Mean & \multicolumn{2}{|l|}{0.68} & \multicolumn{2}{|l|}{0.75} & \multicolumn{2}{|l|}{0.90} \\
\hline Minumum & \multicolumn{2}{|l|}{0.00} & \multicolumn{2}{|l|}{0.26} & \multicolumn{2}{|l|}{0.00} \\
\hline Maximum & \multicolumn{2}{|l|}{1} & \multicolumn{2}{|l|}{1} & \multicolumn{2}{|l|}{1} \\
\hline
\end{tabular}

Table 3 - Technical and scale efficiency measures.

\begin{tabular}{|c|c|c|c|c|c|c|c|c|c|c|}
\hline \multirow{2}{*}{ Efficiency Measures } & \multicolumn{2}{|c|}{ Antalya } & \multicolumn{2}{|c|}{ Konya } & \multicolumn{2}{|c|}{ Ankara } & \multicolumn{2}{|c|}{ Karaman } & \multicolumn{2}{|c|}{ Eskişehir } \\
\hline & Mean & St.d & Mean & St.d & Mean & St.d & Mean & St.d & Mean & St.d \\
\hline $\begin{array}{l}\text { Overall Technical } \\
\text { Efficiency }\left(\mathrm{TE}_{\mathrm{CRS}}\right)\end{array}$ & 0.87 & 0.16 & 0.72 & 0.22 & 0.57 & 0.22 & 0.62 & 0.25 & 0.65 & 0.20 \\
\hline $\begin{array}{l}\text { Pure Technical } \\
\text { Efficiency }\left(\mathrm{TE}_{\mathrm{VRS}}\right)\end{array}$ & 0.90 & 0.15 & 0.76 & 0.21 & 0.66 & 0.20 & 0.69 & 0.21 & 0.72 & 0.18 \\
\hline Scale Efficiency & 0.96 & 0.07 & 0.93 & 0.09 & 0.85 & 0.15 & 0.87 & 0.16 & 0.90 & 0.11 \\
\hline
\end{tabular}

Table 4 - Return to scale by region.

\begin{tabular}{|l|c|c|c|c|c|c|c|c|c|c|}
\hline \multirow{2}{*}{$\begin{array}{l}\text { Return to } \\
\text { scale }\end{array}$} & \multicolumn{2}{|c|}{ Antalya } & \multicolumn{2}{c|}{ Konya } & \multicolumn{2}{c|}{ Ankara } & \multicolumn{2}{c|}{ Karaman } & \multicolumn{2}{c|}{ Eskişehir } \\
\cline { 2 - 14 } & $\begin{array}{l}\text { No. of } \\
\text { Farms }\end{array}$ & $\%$ & $\begin{array}{c}\text { No. of } \\
\text { Farms }\end{array}$ & $\%$ & $\begin{array}{c}\text { No. of } \\
\text { Farms }\end{array}$ & $\%$ & $\begin{array}{c}\text { No. of } \\
\text { Farms }\end{array}$ & $\%$ & $\begin{array}{c}\text { No. of } \\
\text { Farms }\end{array}$ & $\%$ \\
\hline CRS & 44 & 40.00 & 18 & 16.36 & 9 & 8.18 & 14 & 12.73 & 10 & 9.09 \\
\hline DRS & 34 & 30.91 & 22 & 20.00 & 11 & 10.00 & 11 & 10.00 & 18 & 16.36 \\
\hline IRS & 32 & 29.09 & 70 & 63.64 & 90 & 81.82 & 85 & 77.27 & 82 & 74.55 \\
\hline TOTAL & 110 & 100.0 & 110 & 100.0 & 110 & 100.0 & 110 & 100.0 & 110 & 100.0 \\
\hline
\end{tabular}


However, among the efficiency scores of enterprises under $\mathrm{SE}^{2}$, only 7 are below 0.50 . The reason is that the number of enterprises under increasing returns to scale is high.

The average efficiency score under CRS was 0.68 , and this was 0.75 under VRS and 0.90 under SE (Table 2).

As a result of the DEA analysis, $\mathrm{TE}_{\mathrm{CRS}}, \mathrm{TE}_{\mathrm{VRS}}$ and scale efficiencies were calculated separately for the five provinces which constitute the research area (Table 3).

The overall technical efficiency score was highest in Antalya and it was 0.87 . This result shows that even if the farmers reduce input use by $13 \%$, they will achieve the same agricultural income. The province with the lowest total technical efficiency score in the research area is Ankara (0.57). It is noteworthy that Ankara, which has the highest average land width in the research results, has the lowest value among the provinces. In many studies in which the efficiency analysis was applied and the land width was taken as input (Kamruzzaman et al., 2006; Gunduz et al., 2011; Adanacioglu and Olgun, 2012), the results showed that the enterprises with high width also have the higher average efficiency scores. These results increase the importance of other variables used as input in the study.

The results of the land-based return to scale are given in Table 4. According to these results, constant return to scale (CRS) rates in Antalya and Konya are $40 \%$ and $16.36 \%$, respectively. Accordingly, an increase of $1 \%$ in the inputs determined in the research leads to an increase at the same level in agricultural income. The number of farmers in decreasing returns to scale (DRS) was determined in again Antalya and Konya as $30.91 \%$ and with the rate of $20 \%$. As for increasing returns to scale (IRS), the highest number of farmers is in Ankara (81.82\%) and Karaman $(77.27 \%)$ provinces. When these enterprises provide $1 \%$ increase in input amounts, an increase of higher than $1 \%$ in agricultural income occurs.

Table 5 shows the potential improvement table for enterprises that are not determined as efficient according to the results of the study. The difference between the amount of input used by farmers and the optimum input amount is important when considering «the aim is how the input quantity can be reduced without any change in the present output quantity in terms of input efficiency measurement» (Coelli et al., 2005). Land capital, reclamation of land capital, building capital and plant capital are known as fixed assets especially in the classification of working capital are the capitals within enterprises whether production is made or not. Therefore, the cost of these capital groups except for land capital is calculated due to wear and tear. Accordingly, the farmers have to pay attention to the balanced distribution of these capital groups while making the plans of the investment. In enterprises with surplus capital, the cost increases due to the expenses of fixed assets; productivity and efficiency are not achieved because of insufficient working capital; and this situation reflects negatively on agricultural income.

Turkey has the largest share of land capital in active capital in agricultural enterprises. In spite of the increase in intensive farming, mechanization and other capital groups, this fact continues and working capital elements that provide efficiency have not increased essentially. The results of the analysis reveal that there will be no change in agricultural income even if the sample enterprises in Antalya have approximately 36\% less land capital. In Konya, Ankara, Karaman and Eskişehir agricultural enterprises, these rates are determined as $47 \%, 67 \%, 53 \%$, and $63 \%$ respectively.

When the tools-machine capital status of the farmers is examined, it was observed that the farmers who perform traditional agriculture were higher level in quantity and the farmers did not use the existing tools-machine effectively. In agricultural enterprises, the tools-machine are fixed medium-term assets that are subject to fixed costs and they constitute significant cost items including depreciation. In this context, if the tools-machine capital is more than necessary in enterprises, it is not possible to maintain an effective management activity. Research results revealed that farmers in Ankara did not use 


\begin{tabular}{|c|c|c|c|c|c|c|c|c|c|c|c|c|c|c|c|c|}
\hline 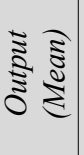 & $0^{-1}$ & 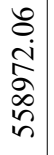 & & & 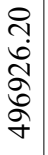 & & & $\begin{array}{c}\hat{o} \\
\dot{a} \\
\stackrel{+}{+} \\
\dot{\alpha}\end{array}$ & & & 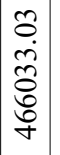 & & & 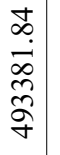 & & \\
\hline \multirow{10}{*}{ 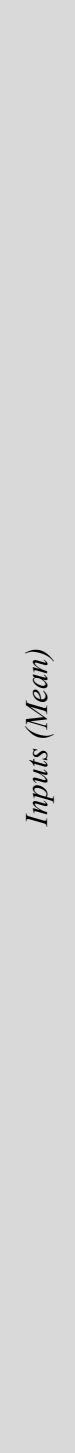 } & $=$ & 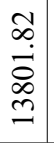 & $\begin{array}{l}0 \\
1 \\
\infty \\
0 \\
0 \\
0\end{array}$ & $\begin{array}{l}\stackrel{P}{i} \\
\text { ñ }\end{array}$ & 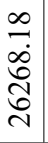 & $\begin{array}{l}\dot{J} \\
\dot{8} \\
\stackrel{8}{n}\end{array}$ & $\begin{array}{l}\stackrel{2}{\circ} \\
\stackrel{\infty}{\infty}\end{array}$ & 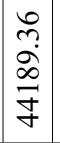 & $\begin{array}{c}\hat{a} \\
\hat{n} \\
=\end{array}$ & $\frac{\stackrel{2}{+}}{+}$ & $\begin{array}{l}n \\
n \\
2 \\
n \\
n \\
n\end{array}$ & $\begin{array}{l}\infty \\
\infty \\
i \\
\infty \\
0 \\
\sim \\
\sim\end{array}$ & $\underset{i}{\stackrel{Z}{i}}$ & 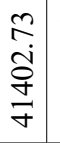 & $\begin{array}{c}0 \\
0 \\
i \\
i n \\
\alpha\end{array}$ & \begin{tabular}{l}
$\infty$ \\
$\infty$ \\
0 \\
\multirow{1}{0}{}
\end{tabular} \\
\hline & $-a$ & $\begin{array}{l}\tilde{n} \\
\approx \\
\approx \\
\approx\end{array}$ & $\begin{array}{l}\overrightarrow{1} \\
\dot{0} \\
\infty \\
\infty\end{array}$ & $\underset{⿱}{\stackrel{J}{+}}$ & $\begin{array}{l}\infty \\
\vec{n} \\
\stackrel{n}{n} \\
n\end{array}$ & $\frac{\hat{n}}{n}$ & $\underset{i}{\stackrel{2}{n}}$ & 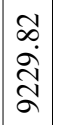 & 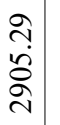 & $\begin{array}{l}\text { N } \\
n \\
\infty \\
0 \\
1\end{array}$ & $\begin{array}{l}0 \\
\infty \\
N \\
\hat{n} \\
n \\
n\end{array}$ & \begin{tabular}{l}
$\infty$ \\
\multirow{+}{0}{} \\
$\dot{0}$ \\
+ \\
$\infty$ \\
-
\end{tabular} & $\begin{array}{l}0 \\
\stackrel{0}{0} \\
\stackrel{0}{0} \\
1\end{array}$ & $\begin{array}{l}\hat{a} \\
\dot{v} \\
\tilde{b}\end{array}$ & $\begin{array}{l}\overrightarrow{\tilde{a}} \\
\tilde{\sim} \\
\stackrel{\sim}{\sim}\end{array}$ & $\begin{array}{l}\infty \\
i \mathfrak{i} \\
i \\
1\end{array}$ \\
\hline & $\sim^{\infty}$ & 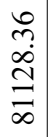 & $\begin{array}{c}\tilde{2} \\
\tilde{n} \\
\tilde{n} \\
\tilde{\sigma}\end{array}$ & $\underset{\sim}{\stackrel{\sim}{7}}$ & $\begin{array}{l}\sigma \\
\sigma \\
\grave{o} \\
\dot{d} \\
\sigma\end{array}$ & $\begin{array}{l}0 \\
\dot{0} \\
\infty \\
\infty \\
n\end{array}$ & $\begin{array}{l}\vec{n} \\
\text { ra }\end{array}$ & $\begin{array}{l}\bar{a} \\
\dot{a} \\
\bar{a} \\
\delta\end{array}$ & $\begin{array}{l}\tilde{\infty} \\
\dot{J} \\
\underset{J}{J}\end{array}$ & $\frac{\infty}{0}$ & $\begin{array}{l}\hat{n} \\
\hat{\sigma} \\
\frac{1}{a}\end{array}$ & 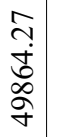 & $\begin{array}{l}\stackrel{0}{0} \\
\ddot{\sim} \\
\dot{1}\end{array}$ & $\begin{array}{l}\infty \\
\stackrel{\infty}{\dot{2}} \\
\infty \\
0 \\
0\end{array}$ & 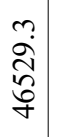 & 守 \\
\hline & $\rightarrow$ & $\begin{array}{l}\vec{\sigma} \\
\hat{\sigma} \\
\hat{\sigma} \\
\hat{n}\end{array}$ & \begin{tabular}{l}
$m$ \\
\hdashline \\
$\infty$ \\
$\infty$ \\
$\infty$ \\
$\infty$ \\
$n$
\end{tabular} & 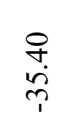 & 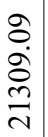 & 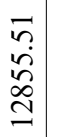 & $\begin{array}{l}\hat{\sigma} \\
\stackrel{9}{1}\end{array}$ & $\left|\begin{array}{c}\tilde{b} \\
\dot{\sigma} \\
0 \\
\tilde{\sigma}\end{array}\right|$ & $\begin{array}{c}0 \\
m \\
\infty \\
\infty \\
0 \\
\infty\end{array}$ & $\frac{n}{n}$ & 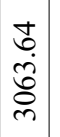 & $\begin{array}{l}0 \\
0 \\
\stackrel{0}{0} \\
0\end{array}$ & $\stackrel{9}{\stackrel{9}{y}}$ & 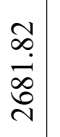 & $\begin{array}{c}\tilde{n} \\
\tilde{v} \\
\stackrel{v}{m} \\
\end{array}$ & $\begin{array}{l}\dot{\sigma} \\
\stackrel{\sigma}{+}\end{array}$ \\
\hline & - & $\begin{array}{l}n \\
\stackrel{n}{f} \\
i\end{array}$ & $\begin{array}{c} \pm \\
0 \\
i \\
n \\
\tilde{n} \\
\tilde{\sigma}\end{array}$ & $\underset{T}{\stackrel{\Xi}{\leftrightarrows}}$ & $\begin{array}{l}\bar{a} \\
\stackrel{\partial}{ } \\
\infty \\
\tilde{n}\end{array}$ & $\begin{array}{l}\infty \\
0 \\
\dot{0} \\
\stackrel{n}{n} \\
\stackrel{n}{n}\end{array}$ & $\begin{array}{l}\underset{+}{+} \\
\underset{\infty}{0}\end{array}$ & 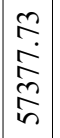 & 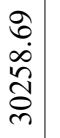 & $\begin{array}{l}\stackrel{\circ}{N} \\
\stackrel{+}{+}\end{array}$ & $\begin{array}{l}\vec{\sigma} \\
0 \\
\hat{\sigma} \\
0 \\
n\end{array}$ & 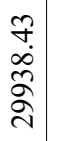 & 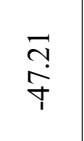 & $\begin{array}{l}\vec{a} \\
\dot{\delta} \\
\stackrel{+}{n} \\
\dot{n}\end{array}$ & 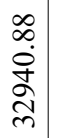 & $\stackrel{\infty}{\stackrel{0}{9}}$ \\
\hline & $\sim$ & 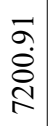 & $\begin{array}{l}\vec{J} \\
\dot{0} \\
\infty \\
\stackrel{\sim}{\sim}\end{array}$ & $\begin{array}{l}\text { †े. } \\
\text { \& }\end{array}$ & 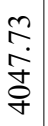 & $\begin{array}{l}\hat{\sigma} \\
\hat{\sim} \\
\tilde{n}\end{array}$ & 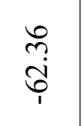 & $\begin{array}{l}\vec{\alpha} \\
\dot{\alpha} \\
\tilde{m}\end{array}$ & $\begin{array}{l}\tilde{n} \\
\tilde{y} \\
\infty\end{array}$ & $\frac{i}{\stackrel{7}{r}}$ & $\begin{array}{l}\dot{J} \\
\dot{\sigma} \\
\tilde{\sim}\end{array}$ & $\begin{array}{l}n \\
n \\
\infty \\
\infty \\
\infty \\
\infty\end{array}$ & 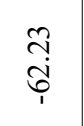 & 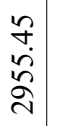 & $\begin{array}{l}m \\
\hat{0} \\
\alpha \\
\alpha\end{array}$ & $\begin{array}{l}\vec{b} \\
\ddot{0} \\
i\end{array}$ \\
\hline & $-^{+}$ & $\begin{array}{l}n \\
\stackrel{n}{n} \\
\tilde{8}\end{array}$ & $\mid \begin{array}{c}0 \\
0 \\
\infty \\
\infty \\
\infty \\
\infty \\
\sigma\end{array}$ & 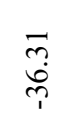 & $\begin{array}{l}\infty \\
\dot{0} \\
\dot{0} \\
\infty \\
\stackrel{2}{\beth}\end{array}$ & 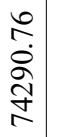 & $\begin{array}{l}\infty \\
\infty \\
\dot{0} \\
+1\end{array}$ & 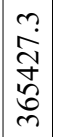 & 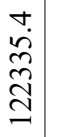 & $\begin{array}{l}\text { Ñ } \\
\stackrel{0}{0} \\
1\end{array}$ & 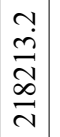 & 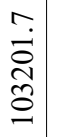 & $\vec{i}$ & $\begin{array}{l}n \\
\hat{\sigma} \\
\frac{n}{2} \\
\stackrel{N}{2}\end{array}$ & $\begin{array}{l}\sim \\
\tilde{\infty} \\
\alpha \\
\tilde{\sigma} \\
0\end{array}$ & $\begin{array}{l}\stackrel{n}{\hat{n}} \\
\text { ஸे } \\
i\end{array}$ \\
\hline & $-n$ & $\begin{array}{l}\infty \\
\infty \\
\tilde{\infty} \\
2 \\
\sigma\end{array}$ & $\mid \begin{array}{l}0 \\
+ \\
\dot{2} \\
8 \\
\infty \\
\infty\end{array}$ & $\begin{array}{l}8 \\
\frac{8}{9}\end{array}$ & 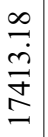 & $\begin{array}{l}\hat{\infty} \\
\dot{\infty} \\
\hat{\sigma} \\
\sigma\end{array}$ & $\begin{array}{l}\text { ô } \\
\stackrel{0}{0} \\
+1\end{array}$ & 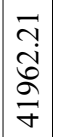 & $\begin{array}{l}\vec{\infty} \\
\dot{\infty} \\
\infty \\
\stackrel{n}{\Sigma}\end{array}$ & $\begin{array}{l}0 \\
\infty \\
\infty \\
i \\
i\end{array}$ & 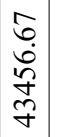 & $\begin{array}{l}3 \\
\stackrel{2}{ } \\
\hat{\infty} \\
\infty\end{array}$ & 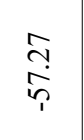 & $\begin{array}{l}\vec{b} \\
\stackrel{\sim}{ } \\
\hat{b} \\
\infty \\
\sim\end{array}$ & $\begin{array}{l}\dot{J} \\
\dot{J} \\
\dot{\Xi} \\
\tilde{n} \\
\end{array}$ & $\begin{array}{l}\hat{\infty} \\
\sim \\
n \\
n\end{array}$ \\
\hline & $\sim^{\sim}$ & $\begin{array}{l}\underset{J}{ \pm} \\
\text { है }\end{array}$ & $\begin{array}{l}0 \\
n \\
n \\
0 \\
8\end{array}$ & $\begin{array}{l}\stackrel{+}{\infty} \\
\stackrel{\dot{\nabla}}{\dot{T}}\end{array}$ & 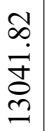 & $\begin{array}{l}\infty \\
\infty \\
\dot{N} \\
\stackrel{\circ}{n}\end{array}$ & $\begin{array}{l}\stackrel{0}{0} \\
\dot{\overrightarrow{0}} \\
1\end{array}$ & $\begin{array}{l}\vec{n} \\
\infty \\
\vec{n} \\
\bar{n}\end{array}$ & $\begin{array}{l}\overrightarrow{0} \\
\stackrel{\hat{\sigma}}{\sigma} \\
\text { (2) }\end{array}$ & 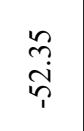 & $\mid \begin{array}{l}\bar{\sigma} \\
\dot{0} \\
\overline{0} \\
\alpha\end{array}$ & 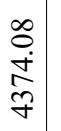 & $\begin{array}{l}\stackrel{g}{+} \\
\dot{+} \\
\stackrel{r}{r}\end{array}$ & $\begin{array}{l}8 \\
0 \\
8 \\
0 \\
0\end{array}$ & 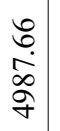 & $\begin{array}{l}\stackrel{2}{\sigma} \\
\text { ñ. }\end{array}$ \\
\hline & - & $\begin{array}{l}\stackrel{R}{\dot{\infty}} \\
\dot{\infty}\end{array}$ & $\begin{array}{l}\infty \\
\infty \\
i \\
\end{array}$ & $\stackrel{m}{\stackrel{r}{r}}$ & $\begin{array}{l}\hat{\alpha} \\
\grave{ٍ} \\
\end{array}$ & $\begin{array}{l}\text { లె } \\
\text { రై }\end{array}$ & $\begin{array}{l}\stackrel{8}{0} \\
\stackrel{+}{+}\end{array}$ & $\begin{array}{c}\tilde{O} \\
\dot{0} \\
\dot{+} \\
\tilde{m}\end{array}$ & $\begin{array}{l}\frac{m}{0} \\
\stackrel{0}{0}\end{array}$ & $\frac{m}{i}$ & $\begin{array}{l}8 \\
\dot{0} \\
\infty \\
0\end{array}$ & $\begin{array}{l}\stackrel{2}{2} \\
\stackrel{2}{ }\end{array}$ & $\stackrel{n}{\stackrel{n}{n}}$ & $\begin{array}{l}\tilde{m} \\
\infty \\
\stackrel{\infty}{0}\end{array}$ & $\begin{array}{l}\dot{\sigma} \\
\dot{0}\end{array}$ & $\begin{array}{l}\text { तે } \\
\text { ભె} \\
1\end{array}$ \\
\hline & $\begin{array}{l}\vec{\pi} \\
\stackrel{\vec{Z}}{0} \\
\frac{0}{4}\end{array}$ & 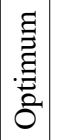 & 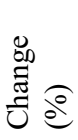 & 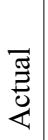 & 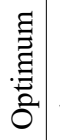 & $\begin{array}{l}\stackrel{\infty}{\infty} \\
\text { 芯 } \\
\text { ¿ }\end{array}$ & 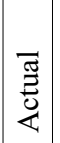 & 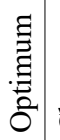 & 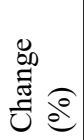 & 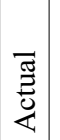 & 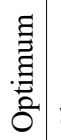 & 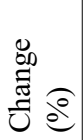 & 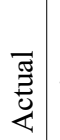 & 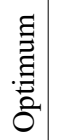 & 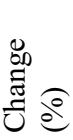 \\
\hline \multicolumn{2}{|l|}{ 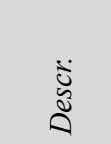 } & \multicolumn{3}{|c|}{ 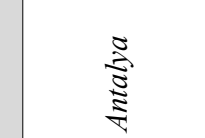 } & \multicolumn{3}{|c|}{$\stackrel{0}{\stackrel{\Xi}{\Delta}}$} & \multicolumn{3}{|c|}{$\frac{\pi}{\frac{\pi}{3}}$} & \multicolumn{3}{|c|}{ 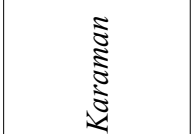 } & \multicolumn{3}{|c|}{ 离 } \\
\hline
\end{tabular}


tools-machine capital effectively. It was determined that farmers in Ankara could obtain the same agricultural income even if they reduced their tools-machine capital amounts by approximately 51\%. In Antalya, Konya, Karaman and Eskişehir agricultural enterprises, these rates were calculated as $19.24 \%, 39.51 \%, 45.66 \%$, and $39.49 \%$, respectively (Table 5).

Such problems increase the importance and level of utilization of agricultural credit for farmers in Turkey as agricultural activities are bound to the natural conditions; risks and uncertainties take place in agricultural activities; the low supply of agricultural products and demand elasticity; fluctuation of agricultural input prices; and payments of input subsidies are not conducted on time. The agricultural credit market, which is important in terms of expanding agricultural enterprises or making new investments, providing effective inputs and meeting their costs, and in short, maintaining economic activities of farmers, has been growing in recent years. Increasing credit volume also forces administrative and legal follow-up in the credit repayment process, and some problems are also evident in the process.

The use of agricultural credits in non-agricultural activities, and the inability of farmers to make economic plans properly have increased the debts of enterprises and they have caused deviations in the proper use of agricultural credits. The research results also revealed that the farmers did not use agricultural credits effectively. In Konya province, it is determined that the farmers do not use $80.96 \%$ of their agricultural credits effectively and this rate is $76.88 \%$ in Eskişehir.

\section{Conclusion}

In the study, it was aimed to measure the success of farmers; the agricultural income was determined and the effective use of different inputs was tried to determine. In agriculture where there are high risk and uncertainty, farmers need to use their resources at an optimum level in order to continue their activities effectively in a risky environment.

The results of the data envelopment analysis revealed that the farmers could not use capital elements effectively and they could achieve the same agricultural income with low capital. In this context, it should be stated that the farmer should correctly determine the distribution of cost-bearing capital elements, even if they do not produce. Keeping accounting records has significance in order to perform correctly in agricultural planning at the macro level in Turkey's agriculture. On the other hand, since most enterprises do not have to keep records, it is important to create incentive and supportive policies for farmers to keep these records.

In Turkish agriculture, it is thought that more product will be obtained by increasing use of inputs. Therefore, the use of inactive inputs are high. Especially, the provinces (Antalya- Konya- Ankara- Karaman- Eskişehir) determined within research scope are the provinces where important product groups are grown and input use is high. In this regard, it may be suggestible to inform them with field demonstration practices for effective input use.

Another important result of the analysis is that agricultural credits have not been used effectively in enterprises. Considering the fact that the main objectives of agricultural credits are to ensure the development of the enterprise and/or to create resources for new investments, the results of the study revealed that agricultural credits used in Turkey generally have been used to meet periodic needs of enterprises, and for non-agricultural needs. This situation wrests agricultural credits from the main aim of use, increases the mutual borrowing of farmers and increases the anxiety of the future. Farmers whose economic structure is not strong and who cannot make their future plans correctly have begun to abandon their production areas by decreasing their agricultural activities due to increase borrowing. In order to expand their enterprises and achieve more profitable production activities, it is important for the sector to ensure that farmers maintain their agricultural activities at the optimum level, to establish policies for the use of agricultural credits in a planned and correct way, and to increase audits during the agricultural credit utilization phase. It should be ensured that the credit resources in agriculture are used correctly, appropriately and timely, in other words effectively. 
Consequently, from this research, it is clear that enterprises should increase their effectiveness. Activities of all agricultural enterprises must be recorded to develop new policies. It will be effective that increasing the number of farmers registered in Farm Accountancy Data Network system (FADN). The integration of this system into Turkish agriculture has not been fully achieved. This system provides important information about farmers. According to the collected data, the farmer will receive a general assessment of the economic effect of his enterprises. It is important to increase the support price for participation of this system by the Ministry of Agriculture and Forestry.

\section{Acknowledgment}

This study data are taken from the TUBITAK program 2219 project that was carried out by Erdogan Gunes who was a visiting School of Business at Ithaca College of New York City.

\section{References}

Abdallah A.H., 2016. Agricultural credit and technical efficiency in Ghana: is there a nexus? Agricultural Finance Review, 76(2): 309-324.

Adanacioglu H., Olgun A., 2012. Evaluation of the efficiency of organic cotton farmers: A case study from Turkey. Bulgarian Journal of Agricultural Science, 18: 418-428.

Aksöz İ., 1972. Zirai Ekonomiye Giriş (Zirai İşletmecilik-Genel Kısım).

Alemdar T., Oren M.N., 2006. Determinants of technical efficiency of wheat farming in Southeastern Anatolia, Turkey: a nonparametric technical efficiency analysis. Journal of Applied Sciences, 6: 827-830.

Arisoy H., 2004. The usage level of wheat varieties newly improved by agricultural research institutes and their economical analysis with comparison conventional varieties: Example of Konya province. Selçuk University Graduate School of Natural and Applied Sciences Department of Agricultural Economic, Master Thesis. Konya.

Aydın B., 2014. Determining the structural characteristics and productive efficiency of farms in thrace region. Namik Kemal University Graduate School of Natural and Applied Sciences Department of Agricultural Economics, Ph.D. Thesis, Tekirdağ.
Badunenko O., Mozharovskyi P., 2016. Nonparametric frontier analysis using Stata. The Stata Journal, 16: 550-589.

Banker R.D., Charnes A., Cooper W.W., 1984. Some models for estimating technical and scale inefficiencies in data envelopment analysis. Management science, 30: 1078-1092.

Banking Regulation and Supervision Agency, 2017. Basic indicators of Turkish Banking Sector, url: http://www.bddk.org.tr/Veriler/TBS-Temel-Gostergeler-Raporu/14. Date of access: 12.11.2018.

Bishoff J.M., 2008. Agricultural finance and credit. Nova Publishers, Inc.

Boussofiane A., Dyson R.G., Thanassoulis E., 1991. Applied data envelopment analysis. European Journal of Operational Research, 52: 1-15.

Chandio A.A., Jiang Y., Gessesse A.T., Dunya R., 2017. The Nexus of Agricultural Credit, Farm Size and Technical Efficiency in Sindh, Pakistan: A Stochastic Production Frontier Approach. Journal of the Saudi Society of Agricultural Sciences.

Charnes A., Cooper W.W., Rhodes E., 1978. Measuring the efficiency of decision making units. European Journal of Operational Research, 2: 429-444.

Chebil A., Frija A., Thabet C., 2015. Economic efficiency measures and its determinants for irrigated wheat farms in Tunisia: a DEA approach. New Medit, 14: 32-39.

Coelli T.J., Rao D.S.P., O’Donnell C.J., Battese G.E., 2005. An introduction to efficiency and productivity analysis. Springer Science \& Business Media.

Çınar G., 2018. Price volatility transmission among cereal markets: The evidences for Turkey. New Medit, 3: 93-104.

Dhungana B.R., Nuthall P.L., Nartea G.V., 2004. Measuring the economic inefficiency of Nepalese rice farms using data envelopment analysis. Australian Journal of Agricultural and Resource Economics, 48: 347-369.

Doyle J., Green R., 1994. Efficiency and cross-efficiency in DEA: Derivations, meanings and uses. Journal of the operational research society, 45: 567-578.

Enjolras G., Capitanio F., Aubert M., Adinolfi F., 2014. Direct payments, crop insurance and the volatility of farm income: Some evidence in France and in Italy. New Medit, 13: 31-40.

FAO, 2018. Food and Agriculture Organization of the United Nations, url: http://www.fao.org/faostat/ en/\#data/QC. Date of access: 03.10.2018.

Farrell M.J., 1957. The measurement of productive efficiency. Journal of the Royal Statistical Society, Series A (General) 120: 253-290. 
Feder G., Lau L.J., Lin J.Y., Luo X., 1990. The relationship between credit and productivity in Chinese agriculture: A microeconomic model of disequilibrium. American Journal of Agricultural Economics, 72: 1151-1157.

Fraser I., Cordina D., 1999. An application of data envelopment analysis to irrigated dairy farms in Northern Victoria. Australia, Agricultural Systems, 59: 267-282.

Guillen J., Franquesa R., 2015. Price transmission and volatility along the Spanish fresh fish market chain. New Medit, 14: 4-11.

Gunduz O., Ceyhan V., Esengun K., 2011. Measuring the technical and economic efficiencies of the dry apricot farms in Turkey. Journal of Food Agriculture \& Environment, 9: 319-324.

Hundie B., Belay K., Demeke M., 2004. Factors Influencing Repayment of Agricultural Input Loans in Ethiopia: The Case of Two Regions. African Review of Money Finance and Banking: 117-144.

Igwe O.O., Nwaogu D.C., Onyegbule F., 2017. Technical efficiency of poultry enterpreneurs in Abia state: a stochastic frontier approach. Scientific Papers Series Management, Economic Engineering in Agriculture Rural Development, 17(1): 241-248.

Kamruzzaman M., Manos B., Begum M.A.A., 2006. Evaluation of economic efficiency of wheat farms in a region of Bangladesh under the input orienta- tion model. Journal of the Asia Pacific Economy, 11: 123-142.

Katchova A.L., 2005. Factors affecting farm credit use. Agricultural Finance Review, 65: 17-29.

Khandker S.R., Faruqee R.R., 2003. The impact of farm credit in Pakistan. Agricultural Economics, 28:197-213.

Özkan U., Erkuş A., 2003. Economic analysis of cattle fattening farms in Bayburt Province. Journal of Agricultural Sciences, 9: 467-472.

Say1lı M., Esengün K., 2002. Economic analysis of cattle fattening farms in Suluova district of Amasya Province. Journal of Agricultural Faculty of Gaziosmanpasa Universty, 19: 51-67.

Şili Ş., 2013. Efficiency analysis of farms producing tomato in Bafra district of Samsun. Ondokuz Mayis Universty Graduate School of Natural and Applied Sciences Department of Agricultural Economics, MasterThesis.

TurkStat, 2018. Agricultural area by province, url: http://www.tuik.gov.tr/PreTablo.do?alt_id=100. Date of access: 05.08.2018.

Ünlüer M., Güneș E., 2013. An analysis of factors affecting repayment of agricultural credits. Journal of Agricultural Faculty of Gaziosmanpasa Universty, 30: 86-92.

Zuberi H.A., 1989. Production function, institutional credit and agricultural development in Pakistan. The Pakistan Development Review: 43-55. 
